\title{
Atmospheric Wet Deposition of PCDD/Fs in the Ambient Air
}

Aerosol and Air Quality Research

\section{OPEN ACCESS}

Received: April 22, 2021

Revised: May 18, 2021

Accepted: May 18, 2021

${ }^{*}$ Corresponding Authors:

Kangping Cui

cuikangping@hfut.edu.cn

Hwey-Lin Sheu

sheu@mail.ksu.edu.tw

\section{Publisher:}

Taiwan Association for Aerosol Research

ISSN: $1680-8584$ print

ISSN: 2071-1409 online

cc) Copyright: The Author(s). This is an open access article distributed under the terms of the Creative Commons Attribution License (CC BY 4.0), which permits unrestricted use, distribution, and reproduction in any medium, provided the original author and source are cited.

\author{
Xueying Tian ${ }^{1}$, Kangping Cui ${ }^{1 *}$, Hwey-Lin Sheu ${ }^{2 *}$, Yen-Kung Hsieh ${ }^{3}$, Fanxuan $\mathrm{Yu}^{1}$ \\ ${ }^{1}$ School of Resources and Environmental Engineering, Hefei University of Technology, Hefei \\ 246011, China \\ 2 Department of Environmental Engineering, Kun Shan University, Tainan 71070, Taiwan \\ ${ }^{3}$ Marine Ecology and Conservation Research Center, National Academy of Marine Research, \\ Kaohsiung 80661, Taiwan
}

\section{ABSTRACT}

Wet deposition is an important mechanism for removing air pollutants from the atmosphere. The total PCDD/Fs-WHO 2005 -TEQ wet deposition from 2018-2020 was investigated for Beijing and Tianjin City in this study. In addition, the gas-particle partitioning of wet deposition, the total $\mathrm{PCDD} /$ Fs-WHO 2005 -TEQ concentrations in the rain, the $\mathrm{PM}_{2.5}$-bound total PCDD/Fs-WHO $2005-\mathrm{TEQ}$ content, and the $\mathrm{PM}_{2.5}$ concentration were also studied for Beijing and Tianjin City, respectively. Between 2018 to 2020, as a whole, the average seasonal variations in PCDD/F wet deposition fluxes in spring, summer, fall, and winter were 50.50, 41.47, 23.03 and $16.76 \mathrm{pg} \mathrm{WHO}_{2005}$-TEQ m ${ }^{-2}$ month $^{-1}$, respectively, while in Tianjin, they were 35.30,42.40, 13.37, and $14.77 \mathrm{pg} \mathrm{WHO}_{2005}-\mathrm{TEQ} \mathrm{m}^{-2}$ month $^{-1}$, respectively. Because the two cities have more rainfall in spring and summer than they do in fall and winter, rainfall has a significant influence on the wet deposition flux. In regard to $\mathrm{PCDD} / \mathrm{Fs}-\mathrm{WHO}_{2005}$-TEQ in the rain, in Beijing, the average total PCDD/Fs-WHO 2005 -TEQ concentration in the rain in spring, summer, fall, and winter were 1.70, 0.39, 1.42, and $1.52 \mathrm{pg} \mathrm{WHO} 2005-\mathrm{TEQ} \mathrm{L}^{-1}$, respectively, while those in Tianjin, were $1.73,0.42,1.35$, and $1.88 \mathrm{pg} \mathrm{WHO}_{2005}-\mathrm{TEQ} \mathrm{L}^{-1}$, respectively. The above results show that the total PCDD/Fs-WHO $\mathrm{WH}_{205}-\mathrm{TEQ}$ concentrations in the rain are significantly lower in summer, which is mainly due to the fact that in summer, the total PCDD/Fs$\mathrm{WHO}_{2005}$-TEQ concentrations in the air are lower, and the proportion of the gas phase is increased. When the total PCDD/Fs-WHO $\mathrm{W}_{205}$-TEQ concentrations in the air are washed away by a heavy rainfall, the PCDD/F concentrations are diluted.

Keywords: $\mathrm{PM}_{2.5}$, Wet deposition, PCDD/Fs, Beijing, Tianjin

\section{INTRODUCTION}

Persistent organic pollutants (POPs) have characteristics that include persistence, toxicity, and biological accumulation and have a great impact on air quality (Hao et al, 2021; Sari et al, 2021). As a sub-group of persistent organic pollutants, PCDD/Fs (polydibenzo- $p$-dioxins and polydibenzofurans) are high similar in terms of structure and properties (Schecter et al., 2006). The toxicity of $\mathrm{PCDD} /$ Fs is estimated using the toxicity equivalent (TEQ) of 17 biotoxic homologues. They have high chemical stability and are difficult to be degraded in the atmosphere, soil, and other environmental media (Lee et al., 2016). PCDDs are derivatives of polydibenzo- $p$-dioxins; there are 75 compounds in total, seven of which have strong biotoxicity, while PCDFs, derivatives of polydibenzofuran, have 135 compounds, ten of which are toxic. Studies have shown that the long-term, stable existence of PCDD/Fs in the human body through the food chain will not only cause irreversible mutations, carcinogenesis, and teratogenicity, but will also affect fetal development (Vilavert et al., 2015). The sources of PCDD/Fs mainly include both natural and artificial sources. Industrial activities account for the largest proportion of PCDD/F human sources (Hagenmaier et al., 1994; Alcock et al., 1998). Waste incineration, the pharmaceutical industry, 
and pesticide production processes containing aromatic hydrocarbons and organochlorine all lead to the formation of PCDD/Fs (Ma et al., 2019; Zhan et al., 2019; Qiu et al., 2020). The exhaust gas from automobiles and motorcycles also contains PCDD/Fs (Chen et al., 2020). Studies show that the retarding fuel injection timing will lead to increased emissions, and the emissions of PCDD/Fs of heavy-duty diesel engines are different at different exhaust gas recirculation rates (Chen et al., 2019; Zhao et al., 2019).

The atmospheric environment is the main PCDD/F migration and transformation route. In addition, atmospheric deposition, which involves both dry and wet deposition, is one of the important ways to remove POPs (Redfern et al., 2017). Among them, wet deposition has a significant effect on removing PCDD/Fs in the particle and gas phases in the atmosphere (Moon et al., 2005; Melymuk et al., 2011). In the case of atmospheric wet deposition, precipitation in the atmosphere such as rain, snow, or other forms of water vapor condensates can remove PCDD/Fs (Lohmann and Jones, 1998). Wet deposition flux is related to the rainfall intensity, temperature, and concentration of environmental pollutants (Kaupp and McLachlan, 1998). The concentrations of total PCDD/Fs$\mathrm{WHO}_{2005}$-TEQ in rain can be calculated from rainfall intensity and wet deposition flux.

PCDD/Fs produced by combustion exists in the atmosphere in the form of gas and particle phases (Li et al., 2008). The results show that the distribution behavior of the gas and particle phases is the main factor that determines the environmental trend of PCDD/Fs. Similarly, some studies have shown that PCDD/Fs in the gas phase exist in small amounts due to the degradation reaction in the atmospheric environment, while PCDD/Fs in the particulate phase mainly enter the ecosystem through the atmospheric environment. The gas-particle partition of PCDD/Fs in the ambient air is related to the ambient temperature, humidity, air pressure, and the compounds themselves (Wang et al., 2010; Cheruiyot et al., 2015). Generally speaking, the gas phase ratio of $\mathrm{PCDD} / \mathrm{Fs}$ in summer is much higher than that in winter, and the gas phase ratio of low-molecular homologues is higher than that of high molecular homologues. This is mainly determined by the cold vapor pressure of the compound. The undercooled vapor pressure of low-chlorinated dioxins is higher than that of high-chlorinated dioxins. Therefore, low-chlorinated dioxins are more likely to accumulate in the gas phase. When the temperature drops, part of the gas phase PCDD/Fs is exchanged and transferred to the particulate phase (Oh et al., 2001).

Particulate matter (PM) is an aerosol, which refers to a mixture of solid particles and liquid droplets (Ghosh et al., 2014). In many cities, it has become the primary pollutant affecting air quality and which has attracted extensive attention from people and governments around the world (Querol et al., 2004; Zavala et al., 2013; Wang et al., 2017). The biological effects of PM are mainly related to particle size, which can be divided into coarse particulate matter $\left(\mathrm{PM}_{10}\right)$, fine particulate matter ( $P M_{2.5}$ ), and ultrafine particulate matter (UFPM) according to the aerodynamic diameter (Chow et al., 2015; Lu et al., 2016). The main sources include motor vehicle exhaust, dust, outdoor pollution from industrial and agricultural production processes, and indoor pollution from the burning of fuels as firewood and coal (Bilos et al., 2001; Kong et al., 2014; Alghamdi et al., 2015). $\mathrm{PM}_{2.5}$ has small diameter, significant activity, strong penetrating power, can easily carry toxic and harmful substances, and is more harmful to human health than $\mathrm{PM}_{10}$ (Dai et al., 2015). In addition, $\mathrm{PM}_{2.5}$ is an important factor causing haze, and regional air pollution seriously affects environmental air quality (Li et al., 2015). Studied have shown a strong link between air pollution from coal burning and lung cancer mortality (He et al., 1991). A positive correlation between $\mathrm{PM}_{2.5}$ and first hospital diagnoses for Alzhemimer's disease and Parkinson's disease dementia has also been found (Kioumourtzoglou et al., 2016).

In this work, the atmospheric PCDD/F wet deposition, the gas-particle PCDD/F partition in wet deposition, the concentration of total PCDD/Fs-WHO $\mathrm{WH}_{200}-\mathrm{TEQ}$ in the rain, $\mathrm{PM}_{2.5}$-bound total $\mathrm{PCDD} / \mathrm{Fs}-\mathrm{WHO}_{2005}-\mathrm{TEQ}$ content and $\mathrm{PM}_{2.5}$ concentration in Beijing $\left(39^{\circ} 56^{\prime} \mathrm{N}, 116^{\circ} 20^{\prime} \mathrm{E}\right)$ and Tianjin $\left(39^{\circ} 13^{\prime} \mathrm{N}, 117^{\circ} 2^{\prime} \mathrm{E}\right)$ in northern China were investigated for the period 2018-2020.

\section{METHODS}

The monthly mean concentrations of both $\mathrm{PM}_{2.5}$ and $\mathrm{PM}_{10}$, and the monthly temperature and precipitation in both cities were obtained from local air quality monitoring stations, the local weather bureau and the Statistics Yearbook of China. 
The total PCDD/F concentrations were simulated using a regression analysis of the $\mathrm{PM}_{10}$ concentration. Tang et al. (2017) reported that there is a high correlation between $\mathrm{PM}_{10}$ values and total PCDD/F mass concentrations. Their research included the following two regression equations:

$Y_{1}=0.0138 x+0.0472$

$Y_{2}=0.0117 x-0.021$

where $Y_{1}, Y_{2}$ represent the total PCDD/F concentration $\left(\mathrm{pg} \mathrm{m}^{-3}\right)$, and $\mathrm{x}$ represents the $\mathrm{PM}_{10}$ concentration in the ambient air $\left(\mu \mathrm{g} \mathrm{m}^{-3}\right)$.

The final total PCDD/F concentration was the average of $Y_{1}$ and $Y_{2}$.

\subsection{Atmospheric Wet Deposition of PCDD/Fs}

Wet deposition is the removal of particles in the atmosphere by precipitation (rainfall and cloud droplets), where precipitation scavenging accounts for the majority of PCDD/Fs removed from the atmosphere through wet deposition (Huang et al., 2011). The wet deposition flux of $\mathrm{PCDD} / \mathrm{Fs}$ is a combination of both vapor dissolution into rain and removal of suspended particulates through precipitation (Koester and Hites, 1992)

The wet deposition fluxes of PCDD/Fs can be evaluated as:

$\mathrm{F}_{W, T}=\mathrm{F}_{W, \text { dis }}+\mathrm{F}_{W, p}$

$\mathrm{F}_{w, \text { dis }}=\mathrm{C}_{\text {rain, dis }} \times$ Rainfall

$\mathrm{F}_{w, p}=\mathrm{C}_{\text {rain, particle }} \times$ Rainfall,

where $F_{w, T}$ is the wet deposition flux of PCDD/Fs from both vapor dissolution into rain and removal of suspended particulates by precipitation; $F_{w}$, dis is the wet deposition flux contributed by vapor dissolution into rain; $F_{w, p}$ is the wet deposition flux contributed by removal of suspended particulates by precipitation, and Rainfall is the monthly rainfall (m).

\subsection{Gas-Particle Partitioning}

The PCDD/F concentrations in the gas and particle phases, respectively, were calculated using a gas-particle partitioning model as shown in Eq. (6) (Yamasaki et al., 1982; Pankow, 1987; Pankow and Bidleman, 1992):

$K_{p}=\frac{F / T S P}{A}$,

where $K_{p}$ is the temperature-dependent partitioning constant $\left(\mathrm{m}^{3} \mu \mathrm{g}^{-1}\right)$; TSP is the concentration of total suspended particulate matter, which was multiplied by $\mathrm{PM}_{10}$ concentration with 1.24 $\left(\mu \mathrm{g} \mathrm{m}^{-3}\right) ; \mathrm{F}$ is the concentration of the compounds of interest bound to particles $\left(\mathrm{pg} \mathrm{m}^{-3}\right)$, and $A$ is the gaseous concentration of the compound of interest $\left(\mathrm{pg} \mathrm{m}^{-3}\right)$.

Plotting log $K_{p}$ against the logarithm of the subcooled liquid vapor pressure, $P_{L}{ }^{0}$, gives

$\log K_{p}=m_{r} \times \log P_{L}^{0}+b_{r_{1}}$

where $P_{L}{ }^{0}$ is the subcooled liquid vapor pressure $(\mathrm{Pa}) ; m_{r}$ is the cited slope, and $b_{r}$ is the cited $\mathrm{y}$ intercept.

Complete datasets on the gas-particle partitioning of PCDD/Fs in Taiwan have been reported (Chao et al., 2004), with the values $m_{r}=-1.29$ and $b_{r}=-7.2$ where the $R^{2}=0.94$. These values were used in the present study for the purpose of establishing the partitioning constant $\left(K_{p}\right)$ for PCDD/Fs.

A previous study correlated the $P_{L}{ }^{0}$ of $\mathrm{PCDD} / \mathrm{Fs}$ with gas chromatographic retention indexes (GC-RI) on a nonpolar (DB-5) GC-column using $\mathrm{p}, \mathrm{p}^{\prime}$-DDT as a reference standard. The correlation 
has been re-developed as follows (Hung et al., 2002):

$\log P_{L}^{0}=\frac{-1.34(R I)}{T}+1.67 \times 10^{-3}(R I)-\frac{1320}{T}+8.087$

where $R /$ represents the gas chromatographic retention indexes (Donnelly et al., 1987), $T$ is the ambient temperature $(\mathrm{K})$.

\section{RESULTS AND DISCUSSION}

\subsection{Wet Deposition Flux of PCDD/Fs}

From 2018-2020, the monthly average wet deposition fluxes of total PCDD/Fs-WHO 2005 -TEQ in Beijing and Tianjin in the ambient air are shown in Figs. 1 (a) and 1(b). And wet deposition of total PCDD/Fs-WHO2005-TEQ in some countries and regions in the world is shown in Table 1 . The monthly rainfall in Beijing and Tianjin from 2018-2020 is shown in Table 2.

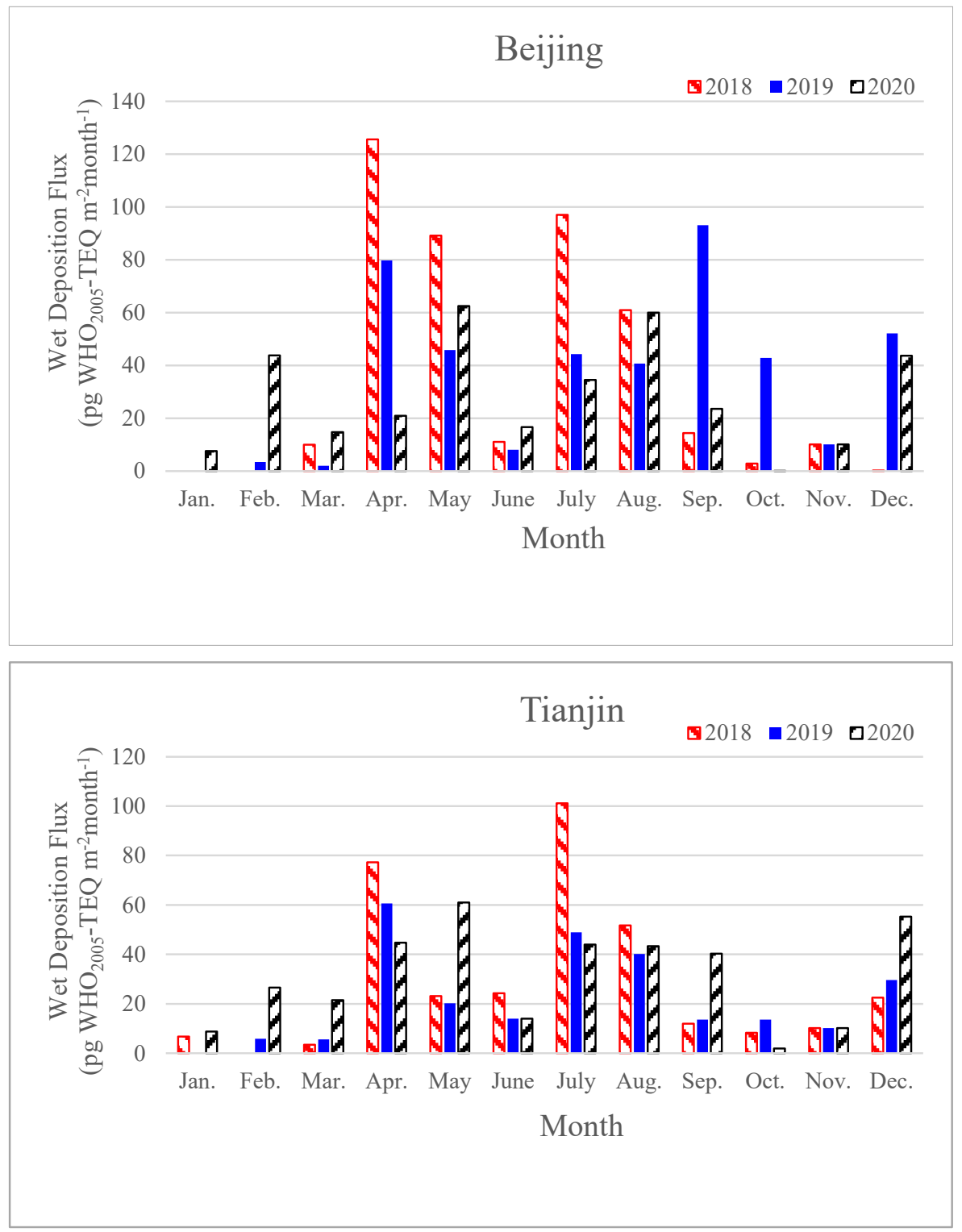

Fig. 1. Monthly average wet deposition fluxes of total PCDD/Fs-WHO2005-TEQ in Beijing and Tianjin in 2018, 2019, and 2020, respectively. 
Table 1. Wet deposition of total PCDD/Fs- $\mathrm{WHO}_{2005}-\mathrm{TEQ}$ in some countries and regions in the world.

\begin{tabular}{llll}
\hline Country & City & Wet deposition $\left(\mathrm{pg} \mathrm{WHO} \mathrm{WHO}_{\left.\text {-TEQ } \mathrm{m}^{-2} \mathrm{month}^{-1}\right)}\right.$ Reference \\
\hline USA & Houston & 360.0 & Correa et al., 2006 \\
Canada & Burlington & 18.5 & Backus et al., 2004 \\
China & Harbin & 30.8 & Zhu et al, 2017b \\
China & Shijiazhuang & 51.8 & Zhu et al, 2017b \\
China & Guangzhou & 47.5 & Zhu et al, 2017a \\
China & Nanjing & 103.3 & Zhu et al, 2017a \\
China & Wuhan & 128.2 & Wang et al, 2018 \\
China & Bengbu & 127.1 & Wang et al, 2018 \\
China & Beijing & 32.8 & This study, 2021 \\
China & Tianjin & 27.1 & This study, 2021 \\
\hline
\end{tabular}

Table 2. Monthly Rainfall (mm) of Beijing and Tianjin from 2018 to 2020.

\begin{tabular}{llllllll}
\hline \multirow{2}{*}{ Month } & \multicolumn{3}{c}{ Beijing } & & \multicolumn{3}{c}{ Tianjin } \\
\cline { 2 - 4 } Jan. & 2018 & 2019 & 2020 & & 2018 & 2019 & 2020 \\
Feb. & 0.0 & 0.0 & 5.1 & & 3.5 & 0.0 & 3.7 \\
Mar. & 0.0 & 2.1 & 34.6 & & 0.0 & 2.5 & 19.7 \\
Apr. & 3.8 & 1 & 11.6 & & 1.4 & 2.8 & 13.5 \\
May & 53.1 & 39.4 & 15.2 & & 37.1 & 29.3 & 27.2 \\
June & 7.9 & 35.7 & 65.4 & & 20.3 & 15.3 & 62.3 \\
July & 59.8 & 15.9 & 29.1 & & 44.8 & 26.3 & 21.2 \\
Aug. & 298.8 & 128.1 & 98.5 & & 304 & 160.4 & 113.5 \\
Sept. & 185 & 151.2 & 200 & & 153.8 & 125.6 & 135.7 \\
Oct. & 26 & 139.2 & 63.5 & & 18.6 & 17 & 84.9 \\
Nov. & 2.6 & 33.9 & 0.1 & & 6.5 & 9.1 & 1.3 \\
Dec. & 2.4 & 28.6 & 30.9 & & 10.1 & 14.5 & 32.8 \\
\hline
\end{tabular}

In 2018, the monthly average wet deposition fluxes of total PCDD/Fs-WHO 2005 -TEQ in Beijing ranged from 0.0 to $125.6 \mathrm{pg} \mathrm{WHO}_{2005}-\mathrm{TEQ} \mathrm{m}^{-2} \mathrm{month}^{-1}$, and the annual total wet deposition flux of total PCDD/Fs-WHO 2005 -TEQ was 421.3 pg $\mathrm{WHO}_{2005}$-TEQ $\mathrm{m}^{-2}$ year $^{-1}$. In 2019, those values

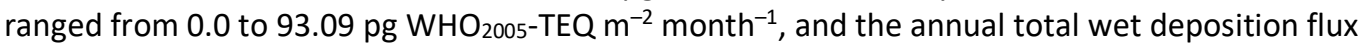
of total PCDD/Fs-WHO 2005 -TEQ was $422.2 \mathrm{pg} \mathrm{WHO}_{2005}$-TEQ $\mathrm{m}^{-2}$ year $^{-1}$. In 2020, those values ranged from 0.13 to $62.50 \mathrm{pg} \mathrm{WHO}_{2005}-\mathrm{TEQ} \mathrm{m}^{-2} \mathrm{month}^{-1}$, and the annual total wet deposition flux of total PCDD/Fs-WHO $2005-\mathrm{TEQ}$ was 338.3 pg $\mathrm{WHO}_{2005}-\mathrm{TEQ} \mathrm{m}^{-2}$ year ${ }^{-1}$. Rainfall has a great influence on the wet deposition flux of PCDD/Fs. Generally, an increase in rainfall will lead to an increase in the wet deposition flux. In 2018, the highest wet deposition flux in Beijing occurred in April (125.6 pg $\mathrm{WHO}_{2005}$-TEQ $\mathrm{m}^{-2}$ month $^{-1}$ ), with $51.33 \mathrm{~mm}$ of rainfall. The lowest value occurred in January and February (almost zero), when there both cities had no rainfall. The month with the largest rainfall in that year was July $(298.9 \mathrm{~mm})$. In 2019, the highest wet deposition flux of PCDD/Fs occurred in September (93.09 $\mathrm{pg} \mathrm{WHO}_{2005}$-TEQ $\mathrm{m}^{-2}$ month ${ }^{-1}$ ), when the monthly rainfall was $139.2 \mathrm{~mm}$. The lowest value occurred in January, at nearly zero. The month with the highest rainfall in the year was August $(151.2 \mathrm{~mm})$. In 2020, the highest wet deposition flux of PCDD/Fs occurred in May (62.50 pg WHO $2005-\mathrm{TEQ} \mathrm{m}^{-2} \mathrm{month}^{-1}$ ), when the monthly rainfall was $65.4 \mathrm{~mm}$.

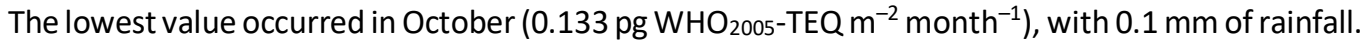
The month with the highest rainfall in the year is August $(200 \mathrm{~mm})$. The above results indicate that the rainfall intensity, the PM size, and the PCDD/F concentration were key factors affecting the wet deposition flux of PCDD/Fs. In terms of the seasonal variations, the four seasons were defined as spring (March, April, May), summer (June, July, August), fall (September, October, November), and winter (January, February and December). In 2018, the average wet deposition fluxes of PCDD/Fs in spring, summer, fall, and winter were 74.91, 56.33, 9.13, 0.06 pg WHO $2005-\mathrm{TEQ} \mathrm{m}^{-2}$ month $^{-1}$, respectively. In 2019, the average wet deposition fluxes were 42.51, 31.03, 48.68, 
$18.52 \mathrm{pg} \mathrm{WHO}_{2005}$-TEQ $\mathrm{m}^{-2}$ month $^{-1}$, respectively, and in 2020, the average wet deposition fluxes were $32.73,37.06,11.28,31.69 \mathrm{pg} \mathrm{WHO}_{2005}$-TEQ $\mathrm{m}^{-2}$ month $^{-1}$, respectively.

As for Tianjin, the monthly average wet deposition fluxes of total PCDD/Fs-WHO $2005-T E Q$ in 2018 ranged from 0.0 to $101.20 \mathrm{pg} \mathrm{WHO}_{2005}$-TEQ $\mathrm{m}^{-2}$ month $^{-1}$, and the annual total wet deposition flux of total PCDD/Fs-WHO 2005 -TEQ was $340.8 \mathrm{pg} \mathrm{WHO}_{2005}-\mathrm{TEQ} \mathrm{m}^{-2}$ year $^{-1}$. In 2019, the values ranged from 0 to $60.60 \mathrm{pg} \mathrm{WHO}_{2005}-\mathrm{TEQ} \mathrm{m}^{-2} \mathrm{month}^{-1}$, and the annual total wet deposition flux of total PCDD/Fs-WHO $2005-\mathrm{TEQ}$ was $262.6 \mathrm{pg} \mathrm{WHO}_{2005}-\mathrm{TEQ} \mathrm{m}^{-2}$ year $^{-1}$. In 2020, the values ranged from 1.96 to $61.03 \mathrm{pg} \mathrm{WHO}_{2005}-\mathrm{TEQ} \mathrm{m}^{-2} \mathrm{month}^{-1}$, and the annual total wet deposition flux of total PCDD/Fs-WHO $2005-T E Q$ was 371.8 pg WHO$_{2005}-\mathrm{TEQ} \mathrm{m}^{-2}$ year $^{-1}$. In terms of the influence of rainfall on wet deposition, in 2018, the highest wet deposition flux in Tianjin occurred in July (101.2 pg $\mathrm{WHO}_{2005}$-TEQ $\mathrm{m}^{-2}$ month $^{-1}$ ), with $304 \mathrm{~mm}$ of rainfall. The lowest value occurred in February (almost zero), with zero rainfall. The rainfall in that month was the lowest of the year. In 2019, the highest wet deposition flux occurred in April (60.60 pg WHO2005-TEQ $\mathrm{W}^{-2}$ month $^{-1}$ ), when the monthly rainfall was $29.3 \mathrm{~mm}$. The lowest value occurred in January (almost zero), with zero rainfall. The month with the highest rainfall in the year was July $(160.4 \mathrm{~mm})$. In 2020, the highest

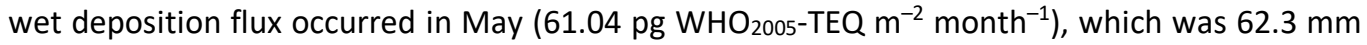
of monthly rainfall. The lowest value occurred in October (1.96 $\mathrm{pg} \mathrm{WHO}_{2005}$-TEQ $\mathrm{m}^{-2} \mathrm{month}^{-1}$ ), which was $1.3 \mathrm{~mm}$ of rainfall. The month with the highest rainfall in the year was August (135.7 $\mathrm{mm}$ ). The above results demonstrated that rainfall has a great influence on wet deposition flux of PCDD/Fs, but it is not the only factor. With regard to seasonal variations, in 2018, the average wet deposition fluxes in spring, summer, fall, and winter were 34.62, 59.07, 10.16, 9.75 pg WHO2005TEQ $\mathrm{m}^{-2}$ month $^{-1}$, respectively. In 2019, they were $28.83,34.36,12.48,11.87 \mathrm{pg} \mathrm{WHO}_{2005}-\mathrm{TEQ}^{-2}$ month $^{-1}$, respectively. In 2020, they were 42.44, 33.78, 17.46, $22.69 \mathrm{pg} \mathrm{WHO}_{2005}$-TEQ m $\mathrm{month}^{-1}$, respectively.

By analyzing the data from the two cities, it can be seen that, in Beijing from 2018 to 2020, the average wet deposition fluxes of PCDD/Fs in spring, summer, fall, and winter were 50.50, 41.47,

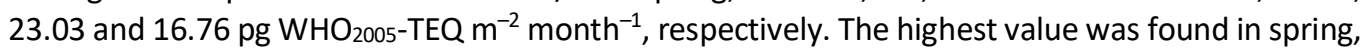
followed by summer and fall, and the lowest value was found in winter. However, in Tianjin, from 2018 to 2020, the seasonal average wet deposition fluxes of PCDD/Fs were 35.30, 42.40, 13.37 and $14.77 \mathrm{pg} \mathrm{WHO}_{2005}$-TEQ $\mathrm{m}^{-2}$ month $^{-1}$, respectively. The highest value was found in summer, followed by spring and winter, and the lowest value was found in fall. This is because there are many factors affecting the wet deposition flux of PCDD/Fs, such as rainfall intensity, PCDD/F concentration, $\mathrm{PM}_{2.5}$ concentration, temperature, and wind speed, all of which will affect the results of PCDD/F wet deposition flux (Suryani et al., 2015).

Table 1 showed the wet deposition of total PCDD/Fs-WHO 2005 -TEQ in some countries and regions in the world. The area with more precipitation did have more amount of PCDD/F wet deposition.

\subsection{Rainfall Intensity}

The rainfall intensity of Beijing and Tianjin in 2018, 2019 and 2020 are shown in Table 2. As for Beijing, in 2018, the rainfall ranged between 0.0 and $298.8 \mathrm{~mm}$ and averaged $53.29 \mathrm{~mm}$; in 2019, it ranged from 0.0 to $151.2 \mathrm{~mm}$ and averaged $48.32 \mathrm{~mm}$, and in 2020, it ranged between 0.1 and $200.0 \mathrm{~mm}$, with an average of $46.23 \mathrm{~mm}$. In 2018, the highest rainfall occurred in July $(298.8 \mathrm{~mm})$ and the lowest values occurred in January (almost zero) and February (almost zero). In both 2019 and 2020, the highest rainfall occurred in August, where the values were 151.2 and $200.0 \mathrm{~mm}$, respectively. In 2019 and 2020, the lowest rainfall occurred in January and October, respectively, when the rainfall was almost zero.

For Tianjin, in 2018, the rainfall ranged between 0.0 and $153.8 \mathrm{~mm}$ and averaged $50.18 \mathrm{~mm}$; in 2019, it ranged from 0.0 to $160.4 \mathrm{~mm}$ and averaged $34.16 \mathrm{~mm}$; while in 2020, it ranged between 0.1 and $135.7 \mathrm{~mm}$ and averaged $42.99 \mathrm{~mm}$. In 2018, the highest rainfall occurred in August (153.8 mm), and the lowest value occurred in February (almost zero). In 2019, the highest rainfall occurred in July $(160.4 \mathrm{~mm})$, and the lowest value occurred in January (almost zero). In 2020, the highest rainfall occurred in August $(135.7 \mathrm{~mm})$ and the lowest value occurred in December $(0.1 \mathrm{~mm})$.

With regard to seasonal variations, for Beijing, in 2018, the rainfall in spring, summer, fall and winter were 21.6, 181.2, 47.00, and $40.67 \mathrm{~mm}$ respectively; in 2019, in that order, it was 25.37, $98.40,67.23,2.27 \mathrm{~mm}$, respectively, and in 2020, it was were 30.73, 109.2, 31.50, $13.47 \mathrm{~mm}$., 
respectively. The results shown that in Tianjin, during 2018, the rainfall in spring, summer, fall, and winter was 19.60, 167.5, 11.87, $1.87 \mathrm{~mm}$, respectively. In 2019 it was 15.8, 104.1, 13.53, 3.20 $\mathrm{mm}$, respectively, and in 2020 it was 34.33, 90.13, 39.67, $7.83 \mathrm{~mm}$, respectively. On the whole, in Beijing, the average rainfall in spring, summer, fall, and winter from 2018 to 2020 was 25.90, 129.6, 48.58, and $18.74 \mathrm{~mm}$, respectively, while in Tianjin, it was 23.24, 93.13, 21.69, and $4.3 \mathrm{~mm}$ respectively. In general, the rainfall in both cities showed obvious seasonal changes, which were all the highest in summer and lowest in winter. According to the previous discussion on wet deposition flux, the lowest value usually occurs in winter, which indicates that the influence of precipitation and number of rainy days on PCDD/F wet deposition flux varies significantly (Lee et al., 2016).

Beijing's climate is a typical semi-humid continental monsoon climate in the northern temperate zone, with summers characterized by high temperatures and rain and winters that are cold and dry. The seasonal distribution of precipitation is very uneven. In 2020, more than 59.0\% of the precipitation was concentrated in June, July, and August. Specifically, $17.8 \%$ of the annual rainfall was in July, and $36.1 \%$ was in August. Tianjin is located in the north temperate zone on the east coast of the Eurasian continent in the middle latitudes. It is mainly dominated by monsoon circulation, and it is a region where the East Asian monsoon is prevalent. It is in the warm temperate zone characterized by a semi-humid monsoon climate. Because it is close to Bohai Bay, the influence of the marine climate on Tianjin is obvious. The main climate features are four distinct seasons: a windy spring with drought and little rain, a hot summer, during which the rain is concentrated, a cool, moderate fall and a cold dry winter with little snow.

\subsection{Gas-Particle Partitioning of Wet Deposition}

Wet deposition refers to the process in which precipitation such as rain, snow and other forms of water vapor in the atmosphere play a role in removing air pollutants. The gas-particle partitioning of PCDD/Fs is an important factor affecting atmospheric dry and wet deposition. Table 3 shows the monthly gas-particle partition contribution on wet deposition in the ambient air in Beijing and Tianjin for the period 2018-2020.

In 2018, 2019 and 2020, in Beijing, the monthly contribution in the particle phase ranged between $73.5 \%$ and $\sim 100 \%, 73.6 \%$ and $~ 100 \%$ and $75.5 \%$ and $99.7 \%$, respectively and averaged 91.4\%. In Tianjin, the monthly contributions ranged between $71.4 \%$ and $100 \%, 73.5 \%$ and $~ 100 \%$ and $74.5 \%$ and $99.7 \%$, respectively and averaged $90.8 \%$. In terms of seasonal variations, during 2018-2020, in Beijing, the seasonal contribution fractions on PCDD/F wet deposition flux by the gas phase were $2.8 \%, 22.4 \%, 5.4 \%$ and $0.2 \%$ in spring, summer, fall, and winter, respectively, and those for Tianjin were $3.4 \%, 2.5 \%, 5.5 \%$ and $0.2 \%$, respectively. The above results revealed that the higher temperature in summer $\left(21.3^{\circ} \mathrm{C}-27.8^{\circ} \mathrm{C}\right)$ led to a higher seasonal percentage of $\mathrm{PCDD} / \mathrm{F}$ wet deposition flux in the gas phase, while the lower temperature (between $-7.0^{\circ} \mathrm{C}$ and $0.7^{\circ} \mathrm{C}$ ) in winter resulted in a lower percentage contribution by the gas phase.

\subsection{Total PCDD/Fs-WHO 2005 -TEQ Concentration in the Rain}

The monthly average concentrations of total PCDD/Fs-WHO2005-TEQ in the rain can be calculated from the rainfall and wet deposition fluxes. The monthly average total PCDD/Fs-WHO $\mathrm{W}_{2005}-\mathrm{TEQ}$ concentrations in the rain from 2018-2020 in Beijing and Tianjin are shown in Figs. 2(a) and 2(b), respectively. It can be seen that the monthly average total PCDD/Fs-WHO 2005 -TEQ concentration in the rain in Beijing in 2018 ranged between 0.32 and $4.23 \mathrm{pg} \mathrm{WHO} \mathrm{WHos}_{-} \mathrm{TEQ}^{-1}$ and averaged $1.52 \mathrm{pg} \mathrm{WHO}_{2005}-\mathrm{TEQ} \mathrm{L}^{-1}$, where July had the lowest $\left(0.32 \mathrm{pg} \mathrm{WHO}_{2005}-\mathrm{TEQ}^{-1}\right.$ ), and November had the highest $\left(4.23 \mathrm{pg} \mathrm{WHO}_{2005}-\mathrm{TEQ} \mathrm{L}^{-1}\right)$. As to the seasonal variations, the average total PCDD/Fs$\mathrm{WHO}_{2005}$-TEQ concentrations in the rain were $2.13,0.40,1.97$, and $1.60 \mathrm{pg} \mathrm{WHO} 2005-\mathrm{TEQ} \mathrm{L}^{-1}$ in spring, summer, fall, and winter, respectively. During 2019, the monthly average total PCDD/Fs$\mathrm{WHO}_{2005}$-TEQ concentrations in the rain ranged between 0.26 and $2.02 \mathrm{pg} \mathrm{WHO}_{2005}-\mathrm{TEQ}^{-1}$ and averaged $1.25 \mathrm{pg} \mathrm{WHO}_{2005}-\mathrm{TEQ} \mathrm{L}^{-1}$, where August had the lowest ( $0.26 \mathrm{pg} \mathrm{WHO} 2005-\mathrm{TEQ} \mathrm{L}^{-1}$ ), and April had the highest $\left(2.02 \mathrm{pg} \mathrm{WHO}_{2005}-\mathrm{TEQ} \mathrm{L}^{-1}\right)$. As to the seasonal variations, the average total $\mathrm{PCDD} / \mathrm{Fs}-\mathrm{WHO}_{2005}$-TEQ concentrations in the rain were 1.76, 0.37, 1.25, and $1.61 \mathrm{pg} \mathrm{WHO}_{2005}-\mathrm{TEQ} \mathrm{L}^{-1}$ in spring, summer, fall, and winter, respectively. During 2020, the monthly average total PCDD/Fs$\mathrm{WHO}_{2005}$-TEQ concentrations in the rain ranged between 0.30 and $1.48 \mathrm{pg} \mathrm{WHO} 2005-\mathrm{TEQ} \mathrm{L}^{-1}$ and averaged $1.00 \mathrm{pg} \mathrm{WHO}_{2005}-\mathrm{TEQ} \mathrm{L}^{-1}$, where August had the lowest $\left(0.30 \mathrm{pg} \mathrm{WHO} \mathrm{WH}_{205}-\mathrm{TEQ} \mathrm{L}^{-1}\right)$, and 
Table 3. Monthly gas-particle partition of wet deposition fluxes in the ambient air in Beijing and Tianjin in 2018, 2019, and 2020, respectively.

\begin{tabular}{|c|c|c|c|c|c|}
\hline \multirow[b]{2}{*}{ Year } & \multirow{2}{*}{$\begin{array}{l}\text { City } \\
\text { Month }\end{array}$} & \multicolumn{2}{|c|}{ Beijing } & \multicolumn{2}{|c|}{ Tianjin } \\
\hline & & Gas(\%) & Particle (\%) & Gas(\%) & Particle (\%) \\
\hline \multirow[t]{12}{*}{2018} & Jan. & 0.0 & $\sim 100$ & 0.2 & 99.8 \\
\hline & Feb. & 0.0 & $\sim 100$ & 0.0 & $\sim 100$ \\
\hline & Mar. & 1.1 & 98.9 & 1.2 & 98.8 \\
\hline & Apr. & 3.1 & 96.9 & 3.6 & 96.4 \\
\hline & May & 8.3 & 91.7 & 10.1 & 89.9 \\
\hline & June & 20.3 & 79.7 & 22.0 & 78.0 \\
\hline & July & 26.5 & 73.5 & 28.7 & 71.3 \\
\hline & Aug. & 25.2 & 74.8 & 26.7 & 73.3 \\
\hline & Sep. & 13.2 & 86.8 & 13.9 & 86.1 \\
\hline & Oct. & 4.2 & 95.8 & 4.9 & 95.2 \\
\hline & Nov. & 3.6 & 96.4 & 1.3 & 98.7 \\
\hline & Dec. & 0.3 & 99.7 & 0.6 & 99.4 \\
\hline \multirow[t]{12}{*}{2019} & Jan. & 0.0 & $\sim 100$ & 0.0 & 100 \\
\hline & Feb. & 0.4 & 99.6 & 0.4 & 99.7 \\
\hline & Mar. & 1.5 & 98.5 & 1.9 & 98.1 \\
\hline & Apr. & 2.9 & 97.1 & 3.2 & 96.8 \\
\hline & May & 8.4 & 91.6 & 9.7 & 90.3 \\
\hline & June & 19.6 & 80.4 & 20.6 & 79.4 \\
\hline & July & 26.4 & 73.6 & 26.5 & 73.5 \\
\hline & Aug. & 24.7 & 75.3 & 24.7 & 75.3 \\
\hline & Sep. & 14.8 & 85.2 & 15.2 & 84.8 \\
\hline & Oct. & 3.9 & 96.1 & 4.6 & 95.4 \\
\hline & Nov. & 0.9 & 99.1 & 1.3 & 98.7 \\
\hline & Dec. & 0.4 & 99.6 & 0.6 & 99.4 \\
\hline \multirow[t]{12}{*}{2020} & Jan. & 0.3 & 99.7 & 0.3 & 99.7 \\
\hline & Feb. & 0.6 & 99.4 & 0.8 & 99.2 \\
\hline & Mar. & 1.9 & 98.1 & 1.9 & 98.1 \\
\hline & Apr. & 4.2 & 95.8 & 4.0 & 96.0 \\
\hline & May & 9.2 & 90.8 & 9.5 & 90.5 \\
\hline & June & 10.9 & 89.1 & 18.8 & 81.2 \\
\hline & July & 23.7 & 76.3 & 24.4 & 75.6 \\
\hline & Aug. & 24.5 & 75.5 & 25.5 & 74.5 \\
\hline & Sep. & 17.2 & 82.8 & 16.6 & 83.4 \\
\hline & Oct. & 4.0 & 96.0 & 4.1 & 95.9 \\
\hline & Nov. & 1.3 & 98.7 & 1.6 & 98.4 \\
\hline & Dec. & 0.4 & 99.6 & 0.4 & 99.6 \\
\hline
\end{tabular}

January had the highest (1.48 $\left.\mathrm{pg} \mathrm{WHO}_{2005}-\mathrm{TEQ} \mathrm{L}^{-1}\right)$. As to the seasonal variations, the average total PCDD/Fs-WHO $\mathrm{WH}_{205}$-TEQ concentrations in the rain were 1.20, $0.41,1.04$, and $1.34 \mathrm{pg} \mathrm{WHO}_{2005}$ TEQ $L^{-1}$ in spring, summer, fall, and winter, respectively.

As for Tianjin, during 2018, the monthly average concentration of total PCDD/Fs-WHO $2005-\mathrm{TEQ}$

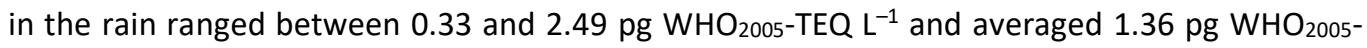
TEQ $\mathrm{L}^{-1}$, which indicated that the July had the lowest $\left(0.33 \mathrm{pg} \mathrm{WHO}_{2005}-\mathrm{TEQ}^{-1}\right)$, and March had the highest $\left(2.49 \mathrm{pg} \mathrm{WHO}_{2005}-\mathrm{TEQ} \mathrm{L}^{-1}\right.$ ). As to the seasonal variations, the average total PCDD/Fs$\mathrm{WHO}_{2005}$-TEQ concentrations in the rain were $1.91,0.40,1.39$, and $1.73 \mathrm{pg} \mathrm{WHO} 2005-\mathrm{TEQ} \mathrm{L}^{-1}$ in spring, summer, fall, and winter, respectively. During 2019, the monthly average concentrations of total PCDD/Fs-WHO $\mathrm{WH}_{205}$-TEQ in the rain ranged between 0.30 and $2.55 \mathrm{pg} \mathrm{WHO} 2005-\mathrm{TEQ} \mathrm{L}^{-1}$ and averaged $1.43 \mathrm{pg} \mathrm{WHO}_{2005}$-TEQ $\mathrm{L}^{-1}$, which indicated that July had the lowest $\left(0.30 \mathrm{pg} \mathrm{WHO}_{2005}\right.$ TEQ $\left.\mathrm{L}^{-1}\right)$, and January had the highest (2.55 $\left.\mathrm{pg} \mathrm{WHO}_{2005}-\mathrm{TEQ} \mathrm{L}^{-1}\right)$. As to the seasonal variations, the average total PCDD/Fs-WHO $2005-\mathrm{TEQ}$ concentrations in the rain were $1.80,0.39,1.45$, and $2.09 \mathrm{pg} \mathrm{WHO}_{2005}-\mathrm{TEQ} \mathrm{L}^{-1}$ in spring, summer, fall, and winter, respectively. During 2020 , the monthly 

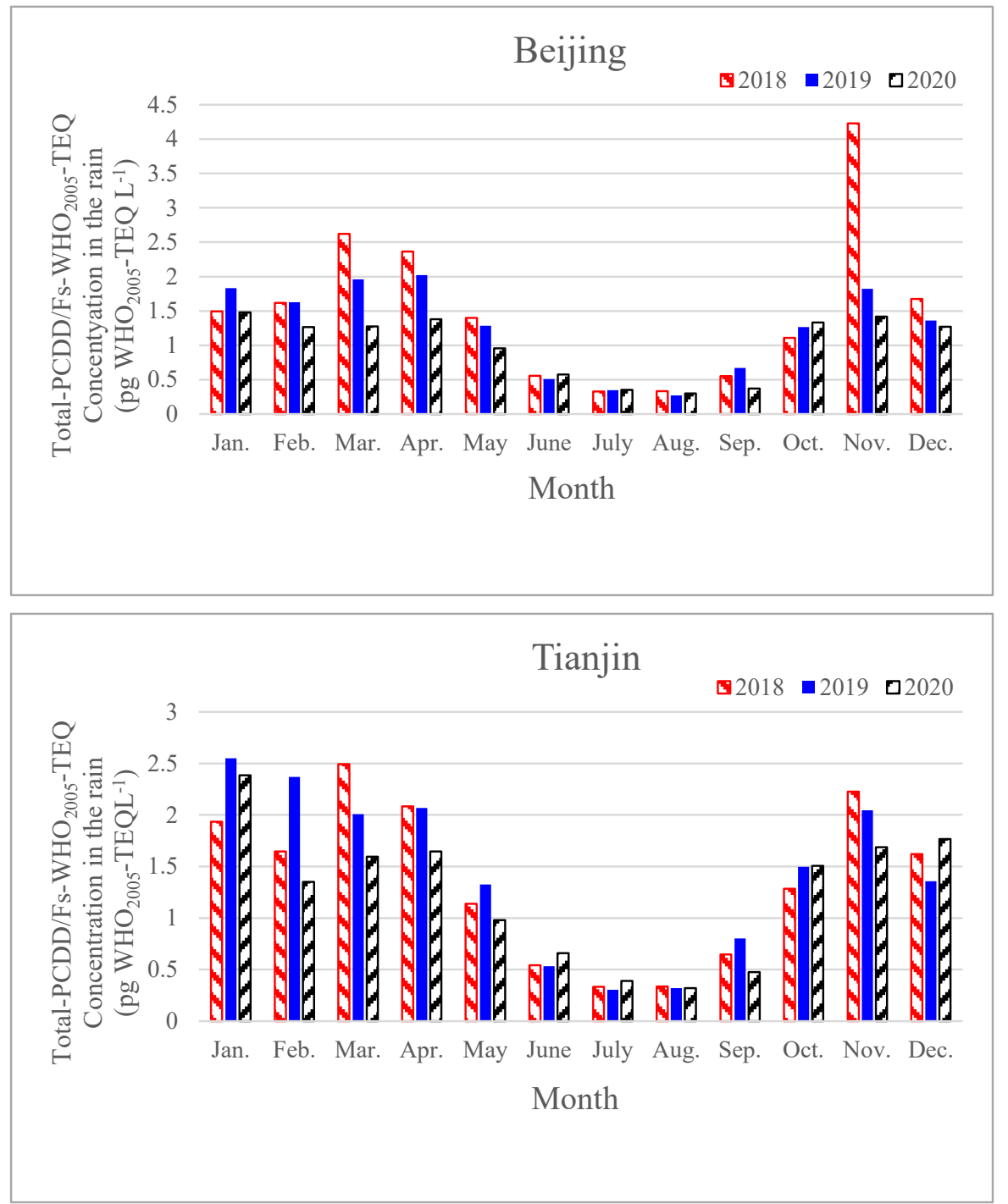

Fig. 2. Monthly average concentrations of total PCDD/Fs-WHO ${ }_{2005}-\mathrm{TEQ}$ in the rain in Beijing and Tianjin in 2018, 2019, and 2020.

average concentrations of total $\mathrm{PCDD} / \mathrm{Fs}-\mathrm{WHO}_{2005}$-TEQ in the rain ranged between 0.32 and $2.39 \mathrm{pg} \mathrm{WHO}_{2005}-\mathrm{TEQ} \mathrm{L}^{-1}$ and averaged $1.23 \mathrm{pg} \mathrm{WHO} 2005-\mathrm{TEQ} \mathrm{L}^{-1}$, which indicated that August had the lowest $\left(0.32 \mathrm{pg} \mathrm{WHO} 2005-\mathrm{TEQ} \mathrm{L}^{-1}\right)$, and January had the highest $\left(2.39 \mathrm{pg} \mathrm{WHO} 2005-\mathrm{TEQ} \mathrm{L}^{-1}\right)$. As to the seasonal variations, the average total PCDD/Fs-WHO $2005-T E Q$ concentrations in the rain were $1.48,0.46,1.22$, and $1.83 \mathrm{pg} \mathrm{WHO}_{2005}-\mathrm{TEQ} \mathrm{L}^{-1}$ in spring, summer, fall, and winter, respectively. The above results showed that the total PCDD/Fs-WHO $\mathrm{WH}_{205}$-TEQ concentration in the rain was

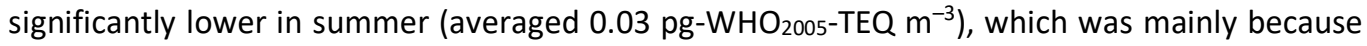
in summer the total PCDD/Fs-WHO 2005 -TEQ concentration in the air is lower (averaged $0.41 \mathrm{pg}$ $\mathrm{WHO}_{2005}$-TEQ $\mathrm{L}^{-1}$ ), and the proportion of the gas phase is increased. When the total PCDD/Fs$\mathrm{WHO}_{2005}$-TEQ concentration in rain is diluted by a heavy rainfall, the PCDD/F concentration is diluted by this greater amount of rain (Wang et al, 2018). However, in winter, the total PCDD/Fs$\mathrm{WHO}_{2005}$-TEQ concentrations in rain were higher, which was due to the low temperature in winter, which resulted in a greater more fraction of PCDD/Fs being adsorbed into the granular phase and easily scavenged by the precipitation (Zhu et al., 2017b).

\section{5 $\mathrm{PM}_{2.5}$-bound Total PCDD/Fs-WHO 2005 -TEQ Content}

Relevant studies have shown that in summer, the total PCDD/Fs-WHO ${ }_{2005}$-TEQ concentrations in counties in Asia accounts for $36.4 \%$ to $71.5 \%$ of the total concentration in the particle phase. 
The $\mathrm{PM}_{2.5}$-bound total PCDD/Fs-WHO $\mathrm{WH}_{205}$-TEQ content in Beijing and Tianjin in 2018, 2019, and 2020 are shown in Figs. 3(a) and 3(b).

As for Beijing, the $\mathrm{PM}_{2.5}$-bound total PCDD/Fs-WHO $\mathrm{WH}_{205}$-TEQ content ranged between 0.10 and $0.84 \mathrm{ng}-\mathrm{WHO}_{2005}-\mathrm{TEQ} \mathrm{g}^{-1}$, with an average of $0.51 \mathrm{ng}-\mathrm{WHO}_{2005}-\mathrm{TEQ} \mathrm{g}^{-1}$ in 2018. It ranged between 0.13 and $0.78 \mathrm{ng}-\mathrm{WHO}_{2005}-\mathrm{TEQ} \mathrm{g}^{-1}$, with an average of $0.51 \mathrm{ng}-\mathrm{WHO}_{2005}-\mathrm{TEQ} \mathrm{g}^{-1}$ in 2019. In 2020, the level of $\mathrm{PM}_{2.5}$-bound total PCDD/Fs-WHO $2005-\mathrm{TEQ}$ ranged between 0.12 and $0.86 \mathrm{ng}-\mathrm{WHO}_{2005}-$ $\mathrm{TEQ}^{-1}$ and averaged $0.48 \mathrm{ng}-\mathrm{WHO}_{2005}-\mathrm{TEQ} \mathrm{g}^{-1}$. In the three years under observation, the highest $\mathrm{PM}_{2.5}$-bound total PCDD/Fs-WHO 2005 -TEQ content in 2018 and 2020 was in December (0.84 ng$\mathrm{WHO}_{2005}$-TEQ g ${ }^{-1}, 0.86$ ng-WHO ${ }_{2005}-\mathrm{TEQ} \mathrm{g}^{-1}$ ), and the highest $\mathrm{PM}_{2.5}$-bound total PCDD/Fs-WHO 2005 TEQ contents in 2019 was in November $\left(0.78 \mathrm{ng}-\mathrm{WHO}_{2005}-\mathrm{TEQ} \mathrm{g}^{-1}\right)$. July was consistently the month with the lowest $\mathrm{PM}_{2.5}$-bound total PCDD/Fs-WHO 2005 -TEQ content $\left(0.10\right.$ ng-WHO $2005-\mathrm{TEQ} \mathrm{g}^{-1}$, 0.13 ng- $\mathrm{WHO}_{2005}-\mathrm{TEQ} \mathrm{g}^{-1}, 0.12 \mathrm{ng}-\mathrm{WHO}_{2005}-\mathrm{TEQ} \mathrm{g}^{-1}$ ).

With regard to Tianjin, the $\mathrm{PM}_{2.5}$-bound total PCDD/Fs-WHO 2005 -TEQ content in 2018 ranged between 0.12 and $0.87 \mathrm{ng}-\mathrm{WHO}_{2005}-\mathrm{TEQ} \mathrm{g}^{-1}$, with an average of $0.47 \mathrm{ng}-\mathrm{WHO}_{2005}-\mathrm{TEQ} \mathrm{g}^{-1}$. In 2019, it ranged from 0.10 to $0.78 \mathrm{ng}-\mathrm{WHO}_{2005}-\mathrm{TEQ} \mathrm{g}^{-1}$ and averaged $0.48 \mathrm{ng}-\mathrm{WHO}_{2005}-\mathrm{TEQ} \mathrm{g}^{-1}$. During 2020, the $\mathrm{PM}_{2.5}$-bound total PCDD/Fs-WHO 2005 -TEQ content ranged between 0.13 and $0.75 \mathrm{ng}$ $\mathrm{WHO}_{2005}$-TEQ g ${ }^{-1}$ and averaged $0.45 \mathrm{ng}-\mathrm{WHO}_{2005}-\mathrm{TEQ} \mathrm{g}^{-1}$. In the three years under observation,
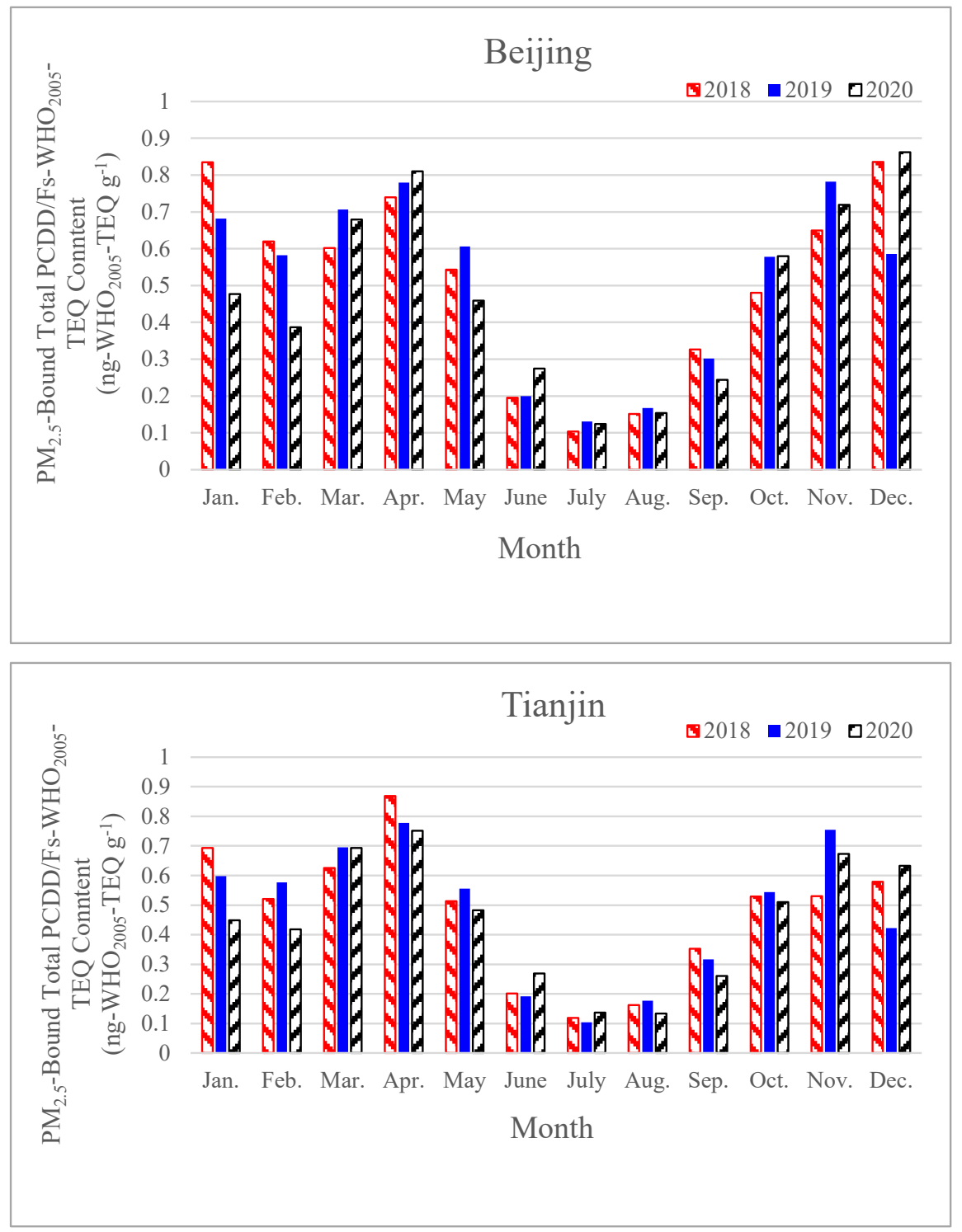

Fig. 3. $\mathrm{PM} 2.5$-bound total $P C D D / F s-W \mathrm{O}_{2005}-\mathrm{TEQ}$ content in Beijing and Tianjin in 2018, 2019, and 2020, respectively. 
the highest $\mathrm{PM}_{2.5}$-bound total PCDD/Fs- $\mathrm{WHO}_{2005}$-TEQ contents were all occurred in April (0.87 ng- $\mathrm{WHO}_{2005}-\mathrm{TEQ} \mathrm{g}^{-1}, 0.78 \mathrm{ng}-\mathrm{WHO}_{2005}-\mathrm{TEQ} \mathrm{g}^{-1}$ and $\left.0.75 \mathrm{ng}-\mathrm{WHO}_{2005}-\mathrm{TEQ} \mathrm{g}^{-1}\right)$. The lowest $\mathrm{PM}_{2.5^{-}}$ bound total PCDD/Fs-WHO $2005-\mathrm{TEQ}$ content in 2018 and 2019 was in July $\left(0.10 \mathrm{ng}-\mathrm{WHO}_{2005}-\mathrm{TEQ} \mathrm{g}^{-1}\right.$, 0.13 ng- $\mathrm{WHO}_{2005}-\mathrm{TEQ} \mathrm{g}^{-1}$ ), and the lowest $\mathrm{PM} 2.5$-bound total PCDD/Fs-WHO $2005-\mathrm{TEQ}$ content in 2020 was in August $\left(0.13\right.$ ng- $\left.\mathrm{WHO}_{2005}-\mathrm{TEQ} \mathrm{g}^{-1}\right)$.

When regard to seasonal variations, for Beijing, in 2018, the $\mathrm{PM}_{2.5}$-bound total PCDD/Fs$\mathrm{WHO}_{2005}$-TEQ content in spring, summer, fall and winter was $0.63,0.15,0.49$, and $0.76 \mathrm{ng}-\mathrm{WHO}_{2005}-$ TEQ $\mathrm{g}^{-1}$, respectively, and in 2019, it was $0.7,0.17,0.55$ and $0.62 \mathrm{ng}-\mathrm{WHO}_{2005}-\mathrm{TEQ} \mathrm{g}^{-1}$, respectively. In 2020, it was $0.22,0.06,0.19$, and $0.25 \mathrm{ng}-\mathrm{WHO}_{2005}-\mathrm{TEQ} \mathrm{g}^{-1}$, respectively. It was found that, in Beijing from 2018 to 2020, the average $\mathrm{PM}_{2.5}$-bound total PCDD/Fs-WHO $2005-\mathrm{TEQ}$ content in summer was approximately $76.8 \%, 69.7 \%$, and $77.2 \%$ lower than that in the other three seasons (spring, fall and winter). The three-year average summer ambient temperature in Beijing was $26.2^{\circ} \mathrm{C}$, which was much higher than the $14.5^{\circ} \mathrm{C}$ in spring, $13.0^{\circ} \mathrm{C}$ in fall and $-3.2^{\circ} \mathrm{C}$ in winter. For Tianjin, in 2018, the $\mathrm{PM}_{2.5}$-bound total PCDD/Fs-WHO $\mathrm{W}_{2005}$-TEQ content in spring, summer, fall, and winter was $0.67,0.16,0.47$, and $0.60 \mathrm{ng}-\mathrm{WHO}_{2005}-\mathrm{TEQ} \mathrm{g}^{-1}$, respectively. In 2019 , it was $0.68,0.16,0.54$, and 0.53 ng-WHO ${ }_{2005}$-TEQ g ${ }^{-1}$, respectively, and in 2020, it was 0.03, 0.01, 0.02, and 0.04 ng- $\mathrm{WHO}_{2005}$-TEQ g ${ }^{-1}$, respectively. The average $\mathrm{PM}_{2.5}$-bound total $\mathrm{PCDD} / \mathrm{Fs}-\mathrm{WHO}_{2005}-$ TEQ content in summer in Tianjin was approximately $76.4 \%, 68.5 \%$, and $72.2 \%$ lower than that in the other three seasons (spring, fall and winter). In Tianjin, the situation was similar. The threeyear average summer ambient temperature in Tianjin was $27.1^{\circ} \mathrm{C}$, which was much higher than the $15.5^{\circ} \mathrm{C}$ in spring, $16.9^{\circ} \mathrm{C}$ in fall and $0^{\circ} \mathrm{C}$ in winter. This was because with the increase in ambient temperature, more of the total PCDD/Fs- $\mathrm{WHO}_{2005}$-TEQ concentration evaporates from the particle phase to the gas phase, resulting in a decrease in the average $\mathrm{PM}_{2.5}$-bound total PCDD/Fs$\mathrm{WHO}_{2005}$-TEQ content.

\section{6 $\mathrm{PM}_{2.5}$ Concentration}

The $\mathrm{PM}_{2.5}$ concentration not only affects human health, but also can reflect the PCDD/F concentration in a given area. This is because the total PCDD/Fs-WHO $2005-\mathrm{TEQ}$ concentration in ambient air mainly comes from the particulate phase. The monthly average $\mathrm{PM}_{2.5}$ concentrations in the ambient air of Beijing and Tianjin are shown in Table 4 for the period between 2018 and 2020. As shown in the Table 4, during 2018-2020 in Beijing, the $\mathrm{PM}_{2.5}$ concentration ranged between 28.0 and 82.0 , between 23.0 and 53.0, and between 24.0 and $62.0 \mu \mathrm{g} \mathrm{m}^{-3}$, and averaged 47.3, 42.0 and $37.9 \mu \mathrm{g} \mathrm{m}^{-3}$, respectively. Over the three years examined, the highest $\mathrm{PM}_{2.5}$ concentration occurred in 2018, followed by 2019 , and the lowest was in 2020 . The annual average $\mathrm{PM}_{2.5}$ concentration was compared between 2018 and 2020, where it was concluded that it was reduced by approximately $19.9 \%$. The decrease in $\mathrm{PM}_{2.5}$ concentration is partly due to the stricter emission regulations for pollutants in Beijing, the capital of China, and partly due to people's increased awareness of environmental protection and efforts. As a whole, the $\mathrm{PM}_{2.5}$ three-year average concentration in Beijing ranged between 23.0 and $82.0 \mu \mathrm{g} \mathrm{m}^{-3}$, with an average of $42.4 \mu \mathrm{g} \mathrm{m}^{-3}$. The highest monthly concentration of $\mathrm{PM}_{2.5}$ occurred in March $\left(82.0 \mu \mathrm{g} \mathrm{m}^{-3}\right)$, while the lowest one occurred in August $\left(23.0 \mu \mathrm{g} \mathrm{m}^{-3}\right)$.

As for Tianjin, over the course of the three years, the highest $\mathrm{PM}_{2.5}$ concentration occurred in 2019 , at $25-81 \mu^{-3} \mathrm{~m}^{-3}$, with an average of $51.3 \mu \mathrm{g} \mathrm{m}^{-3}$; followed by 2018 , which range from $27-$ $79 \mu \mathrm{g} \mathrm{m}^{-3}$, with an average of $48.6 \mu \mathrm{g} \mathrm{m}^{-3}$. In 2020, ranged from 29-101 $\mu \mathrm{g} \mathrm{m}^{-3}$, with an average of $48.0 \mu \mathrm{g} \mathrm{m}^{-3}$. These results indicate that from 2018 to 2020 the annual average $\mathrm{PM}_{2.5}$ concentration fell from 51.3 to $48.0 \mu \mathrm{g} \mathrm{m}^{-3}$, falling by approximately $6.4 \%$. However, the highest values increased by $27.8 \%$ from $2020\left(101 \mu \mathrm{g} \mathrm{m}^{-3}\right)$ to $2018\left(79 \mu \mathrm{g} \mathrm{m}^{-3}\right)$. As a whole, the $\mathrm{PM}_{2.5}$ concentrations for these three years in Tianjin ranged between 25 and $101 \mu \mathrm{g} \mathrm{m}^{-3}$, with an average of $49.3 \mu \mathrm{g} \mathrm{m}^{-3}$. This indicates that the $\mathrm{PM}_{2.5}$ level in Tianjin was higher than that in Beijing. This may due to the fact that Tianjin's coal consumption is much higher than Beijing's, and Beijing has better air pollution control measures. Although Tianjin's air quality has improved annually, these $\mathrm{PM}_{2.5}$ concentrations were still well above the WHO air quality regulated standard $\left(10 \mu \mathrm{g} \mathrm{m}^{-3}\right)$. Therefore, effectively control of $\mathrm{PM}_{2.5}$ emissions must be accomplished to achieve sustainable economic and environmental development in Tianjin.

As for Beijing, the average $\mathrm{PM}_{2.5}$ concentrations in spring, summer, fall, and winter were 62.0, 39.3, 47.0, and $40.7 \mu \mathrm{g} \mathrm{m}^{-3}$ in 2018, respectively, and those during 2019 were 45.7, 33.0, 40.0, 
Table 4. Monthly atmospheric $\mathrm{PM}_{2.5}$ concentration in Beijing and Tianjin in 2018, 2019, and 2020, respectively.

\begin{tabular}{|c|c|c|c|c|c|c|c|}
\hline \multirow[b]{2}{*}{ Year } & \multicolumn{2}{|l|}{ City } & \multicolumn{2}{|l|}{ Beijing } & \multicolumn{3}{|c|}{ Tianjin } \\
\hline & Month & Range & Average & RSD (\%) & Range & Average & RSD (\%) \\
\hline \multirow[t]{12}{*}{2018} & Jan. & $6.0-133$ & 34 & 46 & $9.0-143$ & 53 & 37 \\
\hline & Feb. & $7.0-168$ & 50 & 47 & $11-142$ & 60 & 40 \\
\hline & Mar. & $17-233$ & 82 & 37 & $14-272$ & 75 & 37 \\
\hline & Apr. & 10-206 & 59 & 47 & 14-163 & 44 & 40 \\
\hline & May & $12-128$ & 45 & 32 & $14-80$ & 38 & 23 \\
\hline & June & $8,0-110$ & 43 & 30 & $10-77$ & 40 & 18 \\
\hline & July & $9.0-74$ & 44 & 23 & $8.0-61$ & 38 & 20 \\
\hline & Aug. & $8.0-74$ & 31 & 35 & $8.0-62$ & 29 & 25 \\
\hline & Sep. & $5.0-100$ & 28 & 49 & $8.0-73$ & 30 & 35 \\
\hline & Oct. & $4.0-153$ & 42 & 59 & $7.0-116$ & 44 & 43 \\
\hline & Nov. & $13-220$ & 71 & 43 & $20-225$ & 79 & 35 \\
\hline & Dec. & $6.0-182$ & 38 & 48 & $10-243$ & 53 & 41 \\
\hline \multirow[t]{12}{*}{2019} & Jan. & $9.0-217$ & 51 & 48 & $13-248$ & 81 & 43 \\
\hline & Feb. & 8.0-136 & 53 & 39 & $10-237$ & 78 & 42 \\
\hline & Mar. & $4.0-183$ & 52 & 57 & $10-142$ & 54 & 42 \\
\hline & Apr. & 9.0-106 & 48 & 32 & $15-124$ & 49 & 34 \\
\hline & May & 6.0-91 & 37 & 37 & $8.0-102$ & 41 & 31 \\
\hline & June & $5.0-74$ & 39 & 26 & 10-92 & 42 & 24 \\
\hline & July & $7.0-83$ & 37 & 33 & $22-86$ & 41 & 21 \\
\hline & Aug. & $3.0-76$ & 23 & 40 & $6.0-58$ & 26 & 27 \\
\hline & Sep. & $6.0-77$ & 36 & 33 & $16-78$ & 41 & 27 \\
\hline & Oct. & $6.0-124$ & 40 & 36 & $12-145$ & 50 & 36 \\
\hline & Nov. & $7.0-138$ & 44 & 37 & 14-157 & 51 & 37 \\
\hline & Dec. & $6.0-183$ & 44 & 50 & $10-175$ & 61 & 45 \\
\hline \multirow[t]{12}{*}{2020} & Jan. & 10-107 & 59 & 42 & $15-239$ & 101 & 43 \\
\hline & Feb. & $3.0-207$ & 62 & 48 & $6.0-169$ & 61 & 47 \\
\hline & Mar. & $5.0-117$ & 35 & 44 & $8.0-112$ & 43 & 31 \\
\hline & Apr. & $6.0-90$ & 31 & 40 & $9.0-84$ & 40 & 31 \\
\hline & May & $5.0-108$ & 36 & 38 & $17-66$ & 35 & 24 \\
\hline & June & $7.0-66$ & 32 & 28 & $10-80$ & 38 & 22 \\
\hline & July & $14-85$ & 41 & 25 & $25-75$ & 41 & 16 \\
\hline & Aug. & $9.0-61$ & 28 & 29 & $14-69$ & 34 & 26 \\
\hline & Sep. & $5.0-82$ & 24 & 46 & $8.0-65$ & 29 & 34 \\
\hline & Oct. & $5.0-138$ & 42 & 48 & $8.0-133$ & 54 & 42 \\
\hline & Nov. & $6.0-107$ & 37 & 50 & $12-122$ & 47 & 40 \\
\hline & Dec. & $6.0-72$ & 28 & 38 & $8.0-149$ & 53 & 44 \\
\hline
\end{tabular}

and $49.3 \mu \mathrm{g} \mathrm{m}^{-3}$, respectively. Those in 2020 were $34.0,36.7,34.3$, and $49.7 \mu \mathrm{g} \mathrm{m}^{-3}$, respectively. For Tianjin, during 2018, the average $\mathrm{PM}_{2.5}$ concentrations in spring, summer, fall, and winter were $52.3,35.7,51.0$, and $55.3 \mu \mathrm{g} \mathrm{m}^{-3}$, respectively, and those in 2019 were $48.0,36.3,47.3$, and $73.3 \mu \mathrm{g} \mathrm{m}^{-3}$, respectively. Those in 2020 were $39.3,37.7,43.3$, and $71.7 \mu \mathrm{g} \mathrm{m}^{-3}$, respectively. As can be seen from the above results, the $\mathrm{PM}_{2.5}$ concentration undergoes significant seasonal variations. The highest values always occurred in winter and the lowest always occurred in summer, while the values in spring and fall were similar and in the middle levels. As a whole, Beijing's PM 2.5 concentration in summer $\left(35.3 \mu \mathrm{g} \mathrm{m}^{-3}\right)$ was $32.0 \%$ lower than that in winter $\left(46.6 \mu \mathrm{g} \mathrm{m}^{-3}\right)$ based on a three-year average, and the values of Tianjin in summer $\left(36.6 \mu \mathrm{g} \mathrm{m}^{-3}\right)$ were $82.5 \%$ in magnitude lower than those in winter $\left(66.8 \mu \mathrm{g} \mathrm{m}^{-3}\right)$.

The $\mathrm{PM}_{2.5}$ concentration is highest in winter for the following reasons. Cold temperatures in winter enhance the stability of the atmosphere and hinder the vertical convection of the air, thus resulting in the accumulation of $\mathrm{PM}_{2.5}$ in the ambient air. In addition, heating in northern cities in winter significantly increases the amount of both coal and biomass that are burned, and lower 
temperatures increase vehicle exhaust emissions as well. The lowest $\mathrm{PM}_{2.5}$ concentrations in summer were due to the hot, rainy summer when the instability of the atmosphere is conducive to vertical dispersion and increases in atmospheric humidity, which reduce the $\mathrm{PM}_{2.5}$ concentration in the ambient air.

\section{CONCLUSION}

1. In Beijing from 2018 to 2020, the average wet deposition fluxes of PCDD/Fs in spring, summer, fall, and winter were 50.50, 41.47, 23.03, and $16.76 \mathrm{pg} \mathrm{WHO}_{2005}$-TEQ $\mathrm{m}^{-2}$ month $^{-1}$, respectively. The highest value was found in spring, and the lowest value was found in winter. In Tianjin, from 2018 to 2020, the seasonal average wet deposition fluxes of PCDD/Fs were $35.30,42.40,13.37$, and $14.77 \mathrm{pg} \mathrm{WHO}_{2005}$-TEQ $\mathrm{m}^{-2} \mathrm{month}^{-1}$, respectively. The highest value was found in summer, and the lowest value was found in fall. This is because the two cities have more rainfall in spring and summer, but less in fall and winter, and rainfall has a great influence on the wet deposition flux.

2. As to the seasonal variations, from 2018-2020, in Beijing, the percentages of seasonal contributions to PCDD/F wet deposition fluxes by the gas phase were $2.8 \%, 22.4 \%, 5.4 \%$, and $0.2 \%$ in spring, summer, fall, and winter, respectively, and those of in Tianjin were $3.4 \%, 2.5 \%$, $5.5 \%$, and $0.2 \%$, respectively. The above results revealed that a higher temperature in summer (between $21.3^{\circ} \mathrm{C}$ and $27.8^{\circ} \mathrm{C}$ ) led to a higher seasonal percentage of $\mathrm{PCDD} / \mathrm{F}$ wet deposition fluxes by the gas phase, while those in winter with lower temperature (between $-7.0^{\circ} \mathrm{C}$ and $0.7^{\circ} \mathrm{C}$ ) resulted in a lower contribution by the gas phase.

3. As to seasonal variations, in Beijing, the average concentration of total PCDD/Fs-WHO $2005-\mathrm{TEQ}$ in the rain in spring, summer, fall and winter were $1.70,0.39,1.42$, and $1.52 \mathrm{pg} \mathrm{WHO} 2005-\mathrm{TEQ} \mathrm{L}^{-1}$ from 2018-2020, respectively. In Tianjin, the values in spring, summer, fall and winter were $1.73,0.42,1.35$, and $1.88 \mathrm{pg} \mathrm{WHO}_{2005}$ TEQ L $^{-1}$ from 2018-2020, respectively. The above results showed that the total PCDD/Fs-WHO ${ }_{2005}$-TEQ concentrations in the rain were significantly lower in summer, which is mainly because in summer, the total PCDD/Fs-WHO 2005 -TEQ concentrations in the air are lower, and the proportion of the gas phase is increased. When the total PCDD/Fs$\mathrm{WHO}_{2005}$-TEQ concentration in rain is diluted by a heavy rainfall, the PCDD/F concentration is also diluted by this greater amount of rain. However, in winter, the total PCDD/Fs-WHO 2005 TEQ concentrations in rain were higher, which was due to the low temperature in winter, which caused more PCDD/Fs to be adsorbed into the granular phase and to be more easily scavenged by the precipitation.

4. With regard to seasonal variations, for Beijing, the $\mathrm{PM}_{2.5}$-bound total $\mathrm{PCDD} / \mathrm{Fs}-\mathrm{WHO}_{2005}$-TEQ

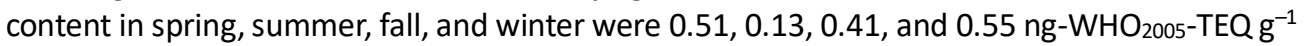
from 2018-2020, respectively. During the three years, the average PM 2.5 -bound total PCDD/Fs$\mathrm{WHO}_{2005}$-TEQ contents in summer were was $76.2 \%, 69.7 \%$, and $77.2 \%$ lower than that in the other three seasons (spring, fall and winter). For Tianjin, the $\mathrm{PM}_{2.5}$-bound total PCDD/Fs-WHO ${ }_{2005}-$ TEQ contents in spring, summer, fall and winter was $0.46,0.11,0.34$ and $0.39 \mathrm{ng}-\mathrm{WHO}_{2005}-$ TEQ g ${ }^{-1}$ from 2018-2020, respectively. The average $\mathrm{PM}_{2.5}$-bound total PCDD/FsWHO 2005 -TEQ content in summer in Tianjin was approximately $76.4 \%, 68.5 \%$ and $72.2 \%$ lower than that in the other three seasons (spring, fall and winter). This was because with an increase in the ambient temperature, more total PCDD/F mass evaporates from the granular phase to the gas phase, resulting in a decrease in the average $\mathrm{PM}_{2.5}$-bound total PCDD/Fs- $\mathrm{WHO}_{2005}$-TEQ contents.

5. As a whole, from 2018-2020, three-year averages of the $\mathrm{PM}_{2.5}$ concentration in Beijing in spring, summer, fall, and winter were $47.2,36.3,37.3$, and $139.7 \mu \mathrm{g} \mathrm{m}{ }^{-3}$, respectively. Beijing's $\mathrm{PM}_{2.5}$ concentration in summer $\left(35.3 \mu \mathrm{g} \mathrm{m}^{-3}\right)$ was $32.0 \%$ lower than that in winter $\left(46.6 \mu \mathrm{g} \mathrm{m}^{-3}\right)$ based on a three-year average. In Tianjin, the values in spring, summer, fall and winter were $46.5,36.6,47.2$, and $66.8 \mu \mathrm{g} \mathrm{m}^{-3}$, respectively. The values of Tianjin in summer $\left(36.6 \mu \mathrm{g} \mathrm{m}^{-3}\right)$ were $82.5 \%$ lower than those in winter $\left(66.8 \mathrm{\mu g} \mathrm{m}^{-3}\right)$ during the three-year period. This means that the $\mathrm{PM}_{2.5}$ concentration exhibits significant seasonal variations. The highest level always occurred in winter and was the lowest in summer, which was related to the atmospheric temperature inversion in the winter time. 


\section{REFERENCES}

Alcock, R.E., Behnisch, P.A., Jones, K.C., Hagenmaier, H. (1998). Dioxin-like PCBs in the environment-human exposure and the significance of sources. Chemosphere 37, 1457-1472. https://doi.org/10.1016/S0045-6535(98)00136-2

Alghamdi, M.A., Almazroui, M., Shamy, M., Redal, M.A., Alkhalaf, A.K., Hussein, M.A., Khoder, M.I. (2015). Characterization and elemental composition of atmospheric aerosol loads during springtime dust storm in western Saudi Arabia. Aerosol Air Qual. Res. 15, 440-453. https://doi.org/10.4209/aaqr.2014.06.0110

Backus, S., Chan, C.H., Williams, D.J., Archer, M.L., Neilson, M.A. (2004). Measurement of wet deposition of polychlorinated dibenzo-p-dioxins and dibenzofurans at Burlington, Ontario, Canada: An initial survey. Organohalogen Compd. 66, 2219-2224.

Bilos, C., Colombo, J.C., Skorupka, C.N., Rodriguez Presa, C.N. (2001). Sources, distribution and variability of airborne trace metals in La Plata City area, Argentina. Environ. Pollut. 111, 149158. https://doi.org/10.1016/S0269-7491(99)00328-0

Chao, M.R., Hu, C.W., Chen, Y.L., Chang-Chien, G.P., Lee, W.J., Chang, L.W., Lee, W.S., Wu, K.Y. (2004). Approaching gas-particle partitioning equilibrium of atmospheric PCDD/Fs with increasing distance from an incinerator: Measurements and observations on modeling. Atmos. Environ. 38, 1501-1510. https://doi.org/10.1016/j.atmosenv.2003.11.034

Chen, H.H., Shen, Y.H., Yang, H.H., Lu, J.H., Wang, L.C., Hsieh, Y.K., Lee, C.F., Lin, S.L. (2020). Newer generation of scooters: Polychlorinated dibenzo- $p$-dioxin and dibenzofuran and polychlorinated biphenyl reductions. Aerosol Air Qual. Res. 20, 1495-1509. https://doi.org/10.4209/aaqr.2020. 04.0138

Chen, S., Cui, K., Zhu, J., Zhao, Y., Wang, L.C., Mutuku, J.K. (2019). Effect of exhaust gas recirculation rate on the emissions of persistent organic pollutants from a diesel engine. Aerosol Air Qual. Res. 19, 812-819. https://doi.org/10.4209/aaqr.2019.01.0047

Cheruiyot, N.K., Lee, W.J., Mwangi, J.K., Wang, L.C., Lin, N.H., Lin, Y.C., Cao, J., Zhang, R., ChangChien, G.P. (2015). An overview: Polycyclic aromatic hydrocarbon emissions from the stationary and mobile sources and in the ambient air. Aerosol Air Qual. Res. 15, 2730-2762. https://doi.org/10.4209/aaqr.2015.11.0627

Chow, J.C., Yang, X., Wang, X., Kohl, S.D., Hurbain, P.R., Chen, L.A., Watson, J.G. (2015). Characterization of ambient $\mathrm{PM}_{10}$ bioaerosols in a California agricultural town. Aerosol Air Qual. Res. 15, 1433-1447. https://doi.org/10.4209/aaqr.2014.12.0313

Correa, O., Rifai, H., Raun, L., Suarez, M., Koenig, L. (2006). Concentrations and vapor-particle partitioning of polychlorinated dibenzo- $p$-dioxins and dibenzofurans in ambient air of Houston, TX. Atmos. Environ. 38, 6687-6699. https://doi.org/10.1016/j.atmosenv.2004.09.005

Dai, S., Bi, X., Chan, L.Y., He, J., Wang, B., Wang, X., Peng, P., Sheng, G., Fu, J. (2015). Chemical and stable carbon isotopic composition of $\mathrm{PM}_{2.5}$ from on-road vehicle emissions in the PRD region and implications for vehicle emission control policy. Atmos. Chem. and Phys. 15, 3097-3108 https://doi.org/10.5194/acp-15-3097-2015

Donnelly, J. R., Munslow, W. D., Mitchum, R. K., Sovocool, G. W. (1987). Correlation of structure with retention index for chlorinated dibenzo-p-dioxins. J. Chromatogr. A 392, 51-63. https://doi.org/10.1016/S0021-9673(01)94253-0

Ghosh, S., Gupta, T., Rastogi, N., Gaur, A., Misra, A., Tripathi, S.N., Paul, D., Tare, V., Prakash, O., Bhattu, D. (2014). Chemical characterization of summertime dust events at Kanpur: Insight into the sources and level of mixing with anthropogenic emissions. Aerosol Air Qual. Res. 14, 879891. https://doi.org/10.4209/aaqr.2013.07.0240

Hagenmaier, H., Lindig, C., She, J. (1994). Correlation of environmental occurrence of polychlorinated dibenzo- $p$-dioxins and dibenzofurans with possible sources. Chemosphere 29, 2163-2174. https://doi.org/10.1016/0045-6535(94)90383-2

Hao, Z., Xu, H.T., Feng, Z.Y., Zhang, C.C., Zhou, X., Wang, Z.F., Zheng, J.H., Zou, X.Q. (2021). Spatial distribution, deposition flux, and environmental impact of typical persistent organic pollutants in surficial sediments in the Eastern China Marginal Seas (ECMSs). J. Hazard. Mater. 407 124343. https://doi.org/10.1016/j.jhazmat.2020.124343

He, X.Z., Chen, W., Liu, Z.Y., Chapman, R.S. (1991). An epidemiological study of lung cancer in Xuan 
Wei County, China: Current progress. Case-control study on lung cancer and cooking fuel. Environ. Health Perspect. 94, 9-13. https://doi.org/10.1289/ehp.94-1567943

Huang, C.J., Chen, K.S., Lai, Y.C., Wang, L.C., Chang-Chien, G.P. (2011). Wet deposition of polychlorinated dibenzo-p-dioxins/dibenzofuran in a rural area of Taiwan. Aerosol Air Qual. Res. 11, 732-748. http://doi.org/10.4209/aaqr.2011.08.0123

Hung, H., Blanchard, P., Poole, G., Thibert, B., Chiu, C.H. (2002). Measurement of particle-bound polychlorinated dibenzo- $p$-dioxins and dibenzofurans (PCDD/Fs) in Arctic air at Alert, Nunavut, Canada. Atmos. Environ. 36, 1041-1050. https://doi.org/10.1016/S1352-2310(01)00498-8

Kaupp, H., McLachlan, M.S. (1998). Atmospheric particle size distributions of polychlorinated dibenzo-pdioxins and dibenzofurans (PCDD/Fs) and polycyclic aromatic hydrocarbons (PAHs) and their implications for wet and dry deposition. Atmos. Environ. 33, 85-95. https://doi.org/ 10.1016/S1352-2310(98)00129-0

Kioumourtzoglou, M.A., Schwartz, J.D., Weisskopf, M.G., Melly, S.J., Wang, Y., Dominici, F., Zanobetti, A. (2016). Long-term $\mathrm{PM}_{2.5}$ exposure and neurological hospital admissions in the northeastern United States. Environ. Health Perspect. 124: 23-29. https://doi.org/10.1289/eh p.1408973

Koester, C.J., Hites, R.A. (1992). Wet and dry deposition of chlorinated dioxins and furans. Environ. Sci. Technol. 26, 1375-1382. https://doi.org/10.1021/es00031a015

Kong, S., Ji, Y., Lu, B., Zhao, X., Han, B., Bai, Z. (2014). Similarities and differences in $\mathrm{PM}_{2.5}, \mathrm{PM}_{10}$ and TSP chemical profiles of fugitive dust sources in a coastal oilfield city in China. Aerosol Air Qual. Res. 14, 2017-2028. https://doi.org/10.4209/aaqr.2013.06.0226

Lee, K.L., Lee, W.J., Mwangi, J.K., Wang, L.C., Gao, X., Chang-Chien, G.P. (2016). Atmospheric PM2.5 and depositions of polychlorinated dibenzo-p-dioxins and dibenzofurans in Kaohsiung area, southern Taiwan. Aerosol Air Qual. Res. 16, 1775-1791. https://doi.org/10.4209/aaqr.2016.04.0168

Li, P., Yan, R., Yu, S., Wang, S., Liu, W., Bao, H. (2015). Reinstate regional transport of PM2.5 as a major cause of severe haze in Beijing. Proc. Natl. Acad. Sci. U.S.A. 112, E2739-E2740. https://doi.org/10.1073/pnas.1502596112

Li, Y.M., Jiang, G.B., Wang, Y.W., Cai, Z.W., Zhang, Q.H. (2008). Concentrations, profiles and gasparticle partitioning of polychlorinated dibenzo- $p$-dioxins and dibenzofurans in the ambient air of Beijing, China. Atmos. Environ. 42, 2037-2047. https://doi.org/10.1016/j.atmosenv.2007.12.005

Lohmann, R., Jones, K.C. (1998). Dioxins and furans in air and deposition: A review of levels, behaviour and processes. Sci. Total Environ. 219, 53-81. https://doi.org/10.1016/S0048-9697 (98)00237-X

Lu, H.Y., Lin, S.L., Mwangi, J.K., Wang, L.C., Lin, H.Y. (2016). Characteristics and source apportionment of atmospheric $\mathrm{PM}_{2.5}$ at a coastal city in Southern Taiwan. Aerosol Air Qual. Res. 16, 1022-1034. https://doi.org/10.4209/aaqr.2016.01.0008

Ma, Y.F., Lin, X.Q., Chen, Z.L., Chen, T., Zhan, M.X., Xu, S.X., Wu, H.L., Li, X.D., Yan, J.H. (2019). Emission characteristics and formation pathways of polychlorinated dibenzo- $p$-dioxins and dibenzofurans from a typical pesticide plant. Aerosol Air Qual. Res. 19, 1390-1399. https://doi.org/10.4209/aaqr.2019.04.0224

Melymuk, L., Robson, M., Diamond, M.L., Bradley, L.E., Backus, S. (2011). Wet deposition loadings of organic contaminants to Lake Ontario: Assessing the influence of precipitation from urban and rural sites. Atmos. Environ. 45, 5042-5049. https://doi.org/10.1016/j.atmosenv.2011.02.007

Moon, H.B., Lee, S.J., Choi, H.G., Ok, G. (2005). Atmospheric deposition of polychlorinated dibenzo-pdioxins (PCDDs) and dibenzofurans (PCDFs) in urbanand suburban areas of Korea. Chemosphere 58, 1525-1534. http://doi.org/10.1016/j.chemosphere.2004.11.014

Oh, J.E., Choi, J.S., Chang, Y.S. (2001). Gas/particle partitioning of polychlorinated dibenzo-pdioxins and dibenzofurans in atmosphere; evaluation of predicting models. Atmos. Environ. 35: 4125-4134. https://doi.org/10.1016/S1352-2310(01)00201-1

Pankow, J.F. (1987). Review and comparative analysis of the theories on partitioning between the gas and aerosol particulate phases in the atmosphere. Atmos. Environ. 21, 2275-2283. https://doi.org/10.1016/0004-6981(87)90363-5

Pankow, J.F., Bidleman, T.F. (1992). Interdependence of the slopes and intercepts from log-log correlations of measured gas-particle paritioning and vapor pressure-l. Theory and analysis of available data. Atmos. Environ. 26, 1071-1080. https://doi.org/10.1016/0960-1686(92)90039-N

Qiu, J., Tang, M.H., Peng, Y.Q., Lu, S.Y., Li, X.D., Yan, J.H. (2020). Characteristics of PCDD/Fs in flue 
gas from MSWIs and HWIs: emission levels, profiles and environmental influence. Aerosol Air Qual. Res. 20, 2085-2097. http://doi.org/ 10.4209/aaqr.2019.11.0610

Querol, X., Alastuey, A., Ruiz, C.R., Artiñano, B., Hansson, H.C., Harrison, R.M., Buringh, E., ten Brink, H.M., Lutz, M., Bruckmann, P. (2004). Speciation and origin of $\mathrm{PM}_{10}$ and $\mathrm{PM}_{2.5}$ in selected European cities. Atmos. Environ. 38, 6547-6555. https://doi.org/10.1016/j.atmosenv.2004.08. 037

Redfern, F.M., Lee, W.J., Yan, P., Mwangi, J.K., Wang, L.C., Shih, C.H. (2017). Overview and perspectives on emissions of polybrominated diphenyl ethers on a global basis: Evaporative and fugitive releases from commercial PBDE mixtures and emissions from combustion sources. Aerosol Air Qual. Res. 17, 1117-1131. https://doi.org/10.4209/aaqr.2016.12.0579

Sari, M.F., Esen, F., Tasdemir, Y. (2021). Levels of Polychlorinated Biphenyls (PCBs) in Honeybees and Bee Products and Their Evaluation with Ambient Air Concentrations. Atmos. Environ. 244, 117903. https://doi.org/10.1016/j.atmosenv.2020.117903

Schecter, A., Birnbaum, L., Ryan, J.J., Constable, J.D. (2006). Dioxins: An overview. Environ. Res. 101, 419-428. https://doi.org/10.1016/j.envres.2005.12.003

Suryani, C.R., Lee, W.J., Endah Mutiara M.P., Mwangi, J.K., Wang, L.C., Lin, N.H., Chang-Chien, G.P. (2015). Atmospheric deposition of polychlorinated dibenzo-p-dioxins and dibenzofurans at coastal and high mountain areas in Taiwan. Aerosol Air Qual. Res. 15, 1390-1411. http://doi.org/10.4209/aaqr.2015.04.0246

Tang, H.Y., Cui, K.P., Xing, J., Zhu, J.N., Lee, W.J., Mwangi, J.K., Lee, Y.C. (2017). Part I: PM2.5 and polychlorinated dibenzo- $p$-dioxins and dibenzofurans (PCDD/Fs) in the ambient air of southern China. Aerosol Air Qual. Res. 17, 1550-1569. https://doi.org/10.4209/aaqr.2017.03.0117

Vilavert, L., Nadal, M., Schuhmacher, M., Domingo, J.L. (2015). Two decades of environmental surveillance in the vicinity of a waste incinerator: Human health risks associated with metals and PCDD/Fs. Arch. Environ. Contam. Toxicol. 69, 241-253. http://doi.org/10.1007/s00244015-0168-1

Wang, J.D., Zhao, B., Wang, S.X., Yang, F.M., Xing, J., Morawska, L., Ding, A.J., Kulmala, M., Kerminen, V.M., Kujansuu, J. (2017). Particulate matter pollution over China and the effects of control policies. Sci. Total Environ. 584, 426-447. https://doi.org/10.1016/j.scitotenv.2017.01.027

Wang, W.W., Cui, K.P., Zhao, R., Lee, W.J., Yan, P. (2018). Sensitivity analyses for atmospheric scavenging ratio of Total PCDD/Fs-TEQ wet deposition: Case of Wuhu City, China. Aerosol Air Qual. Res. 18, 719-733. https://doi.org/10.4209/aaqr.2018.01.0032

Wang, Y.F., Hou, H.C., Li, H.W., Lin, L.F., Wang, L.C., Chang-Chien, G.P., You, Y.S. (2010). Dry and wet depositions of polychlorinated dibenzo- $p$-dioxins and dibenzofurans in the atmosphere in Taiwan. Aerosol Air Qual. Res. 10, 378-390. https://doi.org/10.4209/aaqr.2010.04.0024

Yamasaki, H., Kuwata, K., Miyamoto, H. (1982). Effects of ambient temperature on aspects of airborne polycyclic aromatic hydrocarbons. Environ. Sci. Technol. 16, 189-194. http://doi.org/ 10.1021/es00098a003

Zavala, M., Barrera, H., Morante, J., Molina, L.T. (2013). Analysis of model-based PM2.5 emission factors for on-road mobile sources in Mexico. Atmósfera 26, 109-124. https://doi.org/10.1016/ S0187-6236(13)71065-8

Zhan, M.X., Ma, Y.F., Lin, X.Q., Chen, Z.L., Chen, T., Li, X.D., Yan, J.H. (2019). PCDD/F emission from pharmaceutical industries. Aerosol Air Qual. Res. 19, 2070-2082. https://doi.org/10.4209/aaqr. 2019.06.0284

Zhao, Y.X., Cui, K.P., Zhu, J.N., Chen, S.D., Wang, L.C., Cheruiyot, N.K., Mutuku, J.K. (2019). Effects of retarding fuel injection timing on toxic organic pollutant emissions from diesel engines. Aerosol Air Qual. Res. 19, 1346-1354. https://doi.org/10.4209/aaqr.2019.03.0112

Zhu, J.N., Tang, H.Y, Xing, J., Lee, W.J., Yan, P., Cui, K.P. (2017a). Atmospheric deposition of polychlorinated dibenzo-p-dioxins and dibenzofurans in two cities of Southern China. Aerosol Air Qual. Res. 17, 1798-1801. https://doi.org/10.4209/aaqr.2017.05.0177

Zhu, J.N., Tang, H.Y., Xing, J., Lee, W.J., Yan, P., Cui, K.P. (2017b). Atmospheric deposition of polychlorinated dibenzo- $p$-dioxins and dibenzofurans in two cities of northern China. Aerosol Air Qual. Res. 17, 2027-2040. http://doi.org/10.4209/aaqr.2017.06.0217 